\title{
Experience of Civil Government of Russian Federation Subjects with Institutions of Civil Society in the Sphere of Corruption Counteraction
}

\author{
Igor I. Bikeev, Sergey G. Nikitin, Ildar R. Begishev, Zarina I. Khisamova, Alexandra Yu. \\ Bokovnya
}

\begin{abstract}
The anti-corruption principles established by the legislation of Russia are represented by state cooperation with civil society institutions, international organizations and individuals. This work gives the author's interpretation of "civil society institution" concept. In order to disclose and implement the provisions of the law, they formulate the criteria to classify various associations of citizens as civil society institutions.

The study describes the possible trends of joint activities of regional government bodies of the Russian Federation and civil society institutions on anti-corruption issues.

According to the Decree of the President of Russia, specialized anti-corruption bodies have been created in each constituent entity of the Russian Federation - the commissions for coordination of efforts to combat corruption, which are endowed with serious powers described in the work. The composition of these commissions may include the representatives of public chambers, scientific and educational organizations, as well as public organizations whose statutory tasks is to participate in the fight against corruption. Such a solution makes it possible to increase the transparency of government body activities and improve public control over it.

Based on the results of the work, they formulate main conclusions, proposals and recommendations for state bodies and civil society institutions. The thesis is proved that the principle of cooperation between the state and civil society institutions in the activities of the commissions for anti-corruption work coordination in a number of Russian regions is not implemented or is implemented formally. The statement is substantiated that the inclusion of civil society institution representatives in the commissions is often takes place on the basis of loyalty (“convenient sampling”).
\end{abstract}

Key words: corruption, civil society institutions, involvement rate, subjects of the Russian Federation.

Revised Manuscript Received on November 08, 2019.

* Correspondence Author

Igor I. Bikeev - Doctor of Law, Professor, First Vice-rector, Vice-rector for Research, Honored Lawyer of the Republic of Tatarstan, Senior Researcher, Kazan Innovative University named after V. G. Timiryasov (IEML)

Sergey G. Nikitin - Senior Lecturer, Director of Research Department, Kazan Innovative University named after V. G. Timiryasov (IEML)

Ildar R. Begishev - Ph. D. in Law, Honored Lawyer of the Republic of Tatarstan, Senior Researcher, Kazan Innovative University named after V. G. Timiryasov (IEML)

Zarina I. Khisamova - Ph. D. in Law, Head, Department of Planning and Coordination of Research Activities, Research Department, Krasnodar University of the Ministry of Internal Affairs of the Russian Federation

Alexandra Yu. Bokovnya - Ph. D. in Law, Kazan Federal University, Faculty of Law, Criminal law Department

\section{INTRODUCTION}

Lawyers are well aware of what corruption is and what types of corruption are prosecuted. A quite appropriate discussion about the concept of corruption is conducted mainly because of the definition nuances, depending on which signs of corruption are main and which are secondary according to the authors $[1,2,3,4,5,6]$. Per se, each state independently determines the answers to these questions. At that the answers are close in meaning to each other, if not identical.

At that, during the last 100 years, concepts related to civil society have penetrated into jurisprudence from philosophy, sociology and political science. Despite the fact that the semantic characteristics of the term "civil society" are very vague, this phrase and others formed on its basis have become actively used in judicial practice and in the development of regulatory legal acts. A typical example of this is the Decree of the President of the Russian Federation No. 364 "On the measures improving the organization of activities in the field of anti-corruption" (July 15, 2015) [7]. The Article 2 of the Decree recommends the creation of commissions to coordinate corruption combat efforts in each constituent entity of the Russian Federation. According to the paragraph "d" of the Article 5 of the Model Regulation on the Commission for the Coordination of Work against Corruption in the Subject of the Russian Federation, approved by the Decree, one of the main tasks of the commission, calls "the interaction of executive authorities of the Russian Federation subject and local governments with citizens, civil society institutions, mass media, scientific organizations on anti-corruption issues in the subject of the Russian Federation."

The term "civil society institution" is often used in Russian legislation, but it is not defined by it. There are no official lists of such institutions. This is true of any other country in the world. So far, not a single legislator has formulated an accurate and comprehensive description of "civil society" and "institute of civil society" term meaning. Therefore, to understand these concepts, already enshrined in the rule of law, lawyers have to turn to the scientific works of scholars who are far from modern legal formalism and legal casuistry. The term "civil society" was introduced into the scientific and literary circulation during the IVth century BC by Aristotle, who understood it as a community of free and equal citizens, interconnected by a 
certain form of political structure. In other words, the ancient Greek thinker saw "policy" in civil society [8]. The policy is nothing more than an ancient form of statehood. Thus, according to Aristotle, the concepts of "civil society" and "state" are synonyms.

\section{METHODS}

Based on the interpretation adopted by the authors of "civil society institution" concept, regulatory legal acts, as well as 190 regulatory acts were collected and analyzed using the comparative legal method, on the basis of which the composition of commissions for coordination of work on corruption counteraction was created in all constituent entities of the Russian Federation, with the exception of the Irkutsk Region, Magadan Region and Primorsky Territory, whose documents were not available in free or paid e-mail access. Thus, 82 out of 85 constituent entities of the Russian Federation were studied, that is, $96.47 \%$ of the constituent entities, which allows us to draw mathematically correct conclusions about the level of involvement of civil society institutions in the activities of regional commissions to coordinate counteraction in the constituent entity of the Russian Federation, in the federal district of the Russian Federation and throughout Russia using the statistical method.

It should be noted that mathematical and statistical methods for the study of issues related to corruption, including the effectiveness of anti-corruption, have been used before [9, 10]. The novelty is their use in relation to the subject of this article.

To take into account this level of involvement, the authors used the coefficient of civil society institution involvement and the scale of involvement developed by them. The engagement rate is measured in percent and is calculated by the following formula:

$\mathrm{K}=\mathrm{P} / \mathrm{O} \times 100 \%$, where:

$\mathrm{K}$ is the involvement coefficient of civil society institutions,

$\mathrm{P}$ - the number of civil society representatives in the commission,

$\mathrm{O}$ - the total number of commission members.

In each case, the regional coefficient of involvement means the coefficient of a certain subject of the Russian Federation involvement, the district coefficient of involvement - the coefficient of involvement of a certain federal district of the Russian Federation, uniting a number of subjects.

The involvement scale is a direct line from $0 \%$ to $100 \%$, where:

- $0 \%$ corresponds to the lowest possible level of involvement (civil society institutions are not represented at all);

- the indicator $100 \%$ corresponds to the maximum possible level of involvement (the representatives of civil society institutions occupy all positions in the relevant commission, and state and local authorities are not represented at all).

According to the involvement scale, they determined leaders and outsiders among the subjects and federal districts of Russia.

\section{RESULTS AND DISCUSSION}

Since 2008, a large-scale anti-corruption campaign has been launched in the Russian Federation. This opposition was carried out before, but, starting from the specified year, it took on a much more systemic and structured character. In addition to the traditional criminal law fight against corruption, such areas of activity as programming and anti-corruption work planning, regulation of the requirements for official behavior of state and municipal employees, other officials, prevention and elimination of a conflict of interest, anti-corruption examination of normative legal acts, normative projects of legal acts, etc. were significantly improved.

A large-scale attempt was also made to involve not only law enforcement officers, courts, other government officials in anti-corruption activities, but also the people with an active civic position and the representatives of various non-governmental organizations. Such a measure, as conceived by its initiators, was supposed to increase the transparency of government body activities, create new forms of public control and thereby put forward additional barriers to corruption. In other words, the Russian state has already taken systemic measures that are still being discussed or proposed by scholars in other countries $[11,12]$. Therefore, the attempts to teach Russia $[13,14,15]$ to structure its legal system properly look at least ridiculous. The works that objectively assess the existing realities of corruption in Russia, Western and Eastern countries are a pleasant exception $[16,17,18]$.

It should be noted that public control (its other historical name is popular control) is an institution that has a rich history in Russia. During the time of the Union of Soviet Socialist Republics (hereinafter referred to as the USSR), great attention was paid to it: first, as an instrument of the worker and peasant control who won the revolution over the representatives of deposed classes, then as an instrument of curbing bureaucracy and ensuring social justice. Therefore, such forms of public control as public inspections, public commissions, public checks, etc. were in use. People gathered during their free time, united in various forms established by law, checked the validity of complaints against authorities and organizations, and went to the field to implement test purchases, check discipline, etc. The state granted certain powers to such associations, and such associations acted at different levels of social organization $[19,20]$.

\section{CONCLUSIONS}

1. The principle of cooperation between the state and civil society institutions in the activities of the commissions for the coordination of anti-corruption work in a number of federal subjects is not implemented or is implemented formally.

There are no representatives of civil society institutions in the Kaluga Region, Oryol Region, Trans-Baikal Territory, the Presidium of the Council in Moscow, the Presidium of the Commission in the Komi Republic, the working group of the Sverdlovsk Region Commission. Thus, a clearly low level of interaction between civil society institutions was recorded in 19 out of 85 constituent entities of the Russian Federation. There is indisputable manipulation: thanks to it, the corresponding anti-corruption activity is actually getting out of public control.

It should be noted that the problem of anti-corruption activity "transparency" occurs not only in Russia, but also in all countries of the world. This was discussed in the panel discussion "Who Guards The Guardians: Public Accountability, Transparency, 
And Oversight In Anti-Corruption Initiatives" of "The 2013 American University International Law Review Annual Symposium".

2. Among the representatives of civil society in the commissions for the coordination of anti-corruption efforts, the constituent entities of the Russian Federation the following ones are represented most widely: regional public chambers ( 75 out of 85 constituent entities of the federation), universities (51 out of 85), regional councils of municipalities (18 out of 85 ), and trade industrial chambers (15 out of 85$)$, various public anti-corruption associations (13 out of 85), public organizations of industrialists and entrepreneurs ( 9 out of 85), the public association of Russian lawyers (9 out of 85), the Council of University Rectors of Russia (9 out of 85), trade unions (8 out of 85), public organizations of veterans of the armed forces, law enforcement agencies and special services ( 7 out of 85 ) and a significant number of others.

Private media outlets ( 3 out of 85 ), journalist unions ( 2 out of 85), youth organizations ( 2 out of 85 ), law firms ( 2 out of 85 ), law centers (2 out of 85 ), non-parliamentary parties (there is one representative in the Tambov region), religious organizations (Republic of Dagestan), notarial communities (Jewish Autonomous Region) are represented poorly in the specified commissions. The representation of national-cultural autonomies is completely absent. The anti-corruption potential of a significant number of civil society institutions was not in demand.

3. In order to take part in the commission the representatives of civil society institutions are often selected on the basis of loyalty (the so-called "convenient sampling"). So, the commission includes the representatives of formally independent friends and former colleagues, but in fact affiliated with government bodies, or those who are demonstrably loyal to them. Is it possible to speak of an independent position of civil society if it is represented in the commission, for example, by the head of the Dagestan regional public organization "Supporting the course of the Head of the Republic of Dagestan"? It seems not possible.

Sometimes the status of civil society institution representatives is "assigned" by responsible persons holding relevant state or municipal posts, but with public regalia. The foregoing applies to some members of commissions in the Astrakhan region, Vladimir region, Voronezh region, Trans-Baikal region, Kaliningrad region, Krasnodar region, Krasnoyarsk region, Oryol region, Republic of Bashkortostan, Republic of Buryatia, Republic of Mordovia, Republic of Sakha (Yakutia), Republic of North Ossetia Alania, Republic of Crimea, St. Petersburg, Stavropol Territory, Udmurt Republic, Chuvash Republic, and Chukotka Autonomous Okrug.

4. Interesting and promising areas of interaction between civil society institutions and regional authorities in the fight against corruption are sometimes sabotaged by the indicated authorities, which formally fulfill the established requirements on paper, but not on the merits.

\section{SUMMARY}

The following suggestions follow from the conclusions:

1. To study and rate the dynamics of civil society institution involvement in the activities of commissions annually to coordinate counteraction in the constituent entities of the federation (separately for the Russian Federation and federal districts). It is advisable to arrange a reasonable competition in this matter.

2. To develop and consolidate the criteria for determination of scientific, educational and public organization representatives as the members of commissions in legislation. The commission should include the persons with a sufficient level of competence in the field of anti-corruption policy.

3 . To avoid conflicts of interest during commission members assigning. The commission staffing by the representatives of civil society institutions on the principle of loyalty and reciprocal interactions should not be allowed. Otherwise, they look like a fake, and torn from life.

\section{ACKNOWLEDGEMENTS}

The work is performed according to the Russian Government Program of Competitive Growth of Kazan Federal University. The authors are sincerely grateful to the Kazan Innovative University named after V.G. Timiryasov (IEML) for help in the preparation of this article.

\section{REFERENCES}

1. Coskun, Can Aktan. Political Corruption: An Introductory Study On Terminology And Typology // International Journal Of Social Sciences And Humanity Studies. 2015. Vol. 7. №1. pp. 47-66.

2. Gorsira, Madelijne, Denkers, Adriaan and Huisman, Wim. Both Sides of the Coin: Motives for Corruption Among Public Officials and Business Employees // Journal of Business Ethics. 2018. Vol. 151. pp. 179-194. Available at: https://doi.org/10.1007/s10551-016-3219-2

3. Teachout, Zephyr. Love, Equality, and Corruption // Fordham Law Revue. 2015. Vol. 84. Iss. 2. Article 5. pp. 453-461. Available at: http://ir.lawnet.fordham.edu/flr/vol84/iss $2 / 5$

4. Ouziel, Lauren M. The Regulatory Challenge of Public Corruption // Journal of Criminal Law and Criminology. 2018. Vol. 108. Iss. 3 Article 7. pp. 639-652. Available at: https://scholarlycommons.law.northwestern.edu/jclc/vol108/iss3/7

5. Medina, Jessica. When Rhetoric Obscures Reality: The Definition of Corruption and Its Shortcomings // Loyola of Los Angeles Law Review. 2015. Vol. 48. Iss. 3. Pp. 597-650. Available at: https://digitalcommons.lmu.edu/llr/vol48/iss3/3

6. Lessig, Lawrence What an Originalist Would Understand "Corruption" to Mean // California Law Review. 2014. Vol. 102. Iss. 1. Article 1. pp. 1-24. Available at: https://doi.org/10.15779/Z38DF8D

7. Collection of the Russian Federation legislation. - 2015. - No. 29 (part II). - Art. 4477.

8. Greate encyclopedic dictionary. V. 1. / Ed. in charge A.M. Prokhorov. - M.: Soviet Encyclopedia, 1991. - p. 333.

9. Campbell, Kaycea. A Statistical Analysis of Public Sector Corruption and Economic Growth, // LUX: A Journal of Transdisciplinary Writing and Research from Claremont Graduate University. 2013. Vol. 2: Iss. 1, Article 6. pp. 1-20. Available at: http://scholarship.claremont.edu/lux/vol2/iss1/6

10. Quah, Jon S.T. Combating Asian Corruption: Enhancing The Effectiveness Of Anti-Corruption Agencies // Contemporary Asian Studies Series. 2017, October. pp. 1-83.

11. Meyer Michael, Moder Clara, Neumayr Michaela, Vandor Peter. Civil Society and Its Institutional Context in CEE // International Society for third-sector Research. Voluntas. 2019. 11 March. pp. 1-17. Available at: https://doi.org/10.1007/s11266-019-00106-7

12. Coskun, Can Aktan. Ethics In Government: Anti-Corruption Measures // International Journal Of Social Sciences And Humanity Studies. 2015. Vol. 7. №2. pp. 63-89.

13. Scheimer, Michael. Introduction Symposium: Russia and the Rule of Law: New Opportunities In Domestic and International Affairs // American University International Law Review. 2010. Vol. 25. Iss. 2. Symposium: Russia and the Rule of Law: New Opportunities in Domestic and International Affairs. Article 1. pp. 199-211.

14. Michale, Bryane. Issues in Anti-Corruption Law: Drafting Implementation Regulations for Anti-Corruption Conventions in Central Europe and the Former Soviet Union // Journal of 
Legislation. 2010. Vol. 36. Iss. 2. Article 12. pp. 272-296.

15. Woodruff, David M. Law's Authorizations And Rule Of Law Ideals: Lessons From Russia // GA. J. INT'L \& COMP. Law. 2012. Vol. 41. pp. 157-185.

16. Kuhner, Timothy K. The Corruption of Liberal and Social Democracies // Fordham Law Review. 2016. Vol. 84. Iss. 6. Article 3. pp. 2453-2476.

17. Luo, C., Li, M., Peng, P., \& Fan, S. How Does Internet Finance Influence the Interest Rate? Evidence from Chinese Financial Markets. Dutch Journal of Finance and Management, 2(1), (2018). 01.

18. Araújo, C., Henriques, P. R., \& Martini, R. G. Virtual Learning Spaces Creation Based on the Systematic Population of an Ontology. Journal of Information Systems Engineering \& Management, 3(1), (2018). 07.

19. Escalera Chávez, M. E., Moreno García, E., \& Rojas Kramer, C. A. Confirmatory Model to Measure Attitude towards Mathematics in Higher Education Students: Study Case in SLP Mexico. International Electronic Journal of Mathematics Education, 14(1), (2019). 163-168. https://doi.org/10.29333/iejme/3984

20. Shatilova, L. M., Borisova, V. V., \& Kasatkina, O. A.. Representation of the linguistic and cultural concept "lie" in the French and Russian language picture of the world. Opción, 34(85-2), (2018). 257-276. 